\title{
FORMING-LIMITS ANALYSIS OF THE SUPERPLASTIC 2A97 Al-Li ALLOY
}

\author{
ANALIZA OMEJITEV PREOBLIKOVANJA SUPERPLASTIČNE \\ Al-Li ZLITINE 2A97
}

\author{
Li Jia ${ }^{1}$, Xueping Ren ${ }^{1 *}$, Yanling Zhang ${ }^{2}$, Hongliang $\mathrm{Hou}^{2}$ \\ ${ }^{1}$ School of Materials Science and Engineering, University of Science and Technology Beijing, Beijing 100083, P. R. China \\ ${ }^{2}$ Aviation Industry Corporation of China (AVIC) Manufacturing Technology Institute, Beijing 100024, P. R. China
}

Prejem rokopisa - received: 2019-10-09; sprejem za objavo - accepted for publication: 2019-12-23

doi:10.17222/mit. 2019.240

\begin{abstract}
The superplastic formability of the as-rolled 2A97 Al-Li alloy was studied under various stress states with the use of both tensile tests and bulge tests deformed at $350-430{ }^{\circ} \mathrm{C}$. The flow stress curves of the $2 \mathrm{~A} 97$ alloy at the test temperature with an initial strain rate ranging from $1 \times 10^{-3} \mathrm{~s}^{-1}$ to $3 \times 10^{-2} \mathrm{~s}^{-1}$ were characterized by the modified Hooke equation and the Grosman equation. The bulge tests were performed under four different strain paths, ranging from equi-biaxial to approaching plane strain. The effects of temperature and bulge-tool aspect ratio on the dome height, forming pressure, thickness distribution, and cavitation were investigated. Dome height and forming pressure appear to be more sensitive to tool ratio than temperature. Increasing the temperature in bulge forming was found to improve the thickness distribution in the formed parts, but it may lead to excessive cavitation. The results of the forming-limit diagram show significant scatter in terms of failure strain. It indicates that a determination of the forming limits of superplastic 2A97 cannot be represented with a simple forming-limit diagram and additional metrics for internal cavitation need to be considered.
\end{abstract}

Keywords: superplasticity, 2A97 Al-Li alloy, forming limit, cavitation

Avtorji tega prispevka so študirali superplastično preoblikovanje Al-Li zlitine 2A97 v valjanem stanju pri različnih napetostnih stanjih z uporabo nateznega in vlečnega preizkusa ter deformacijo materiala pri temperaturah med $350{ }^{\circ} \mathrm{C}$ in $430{ }^{\circ} \mathrm{C}$. Krivulje tečenja zlitine 2A97 pri izbranih temepraturah so deformirali z začetno hitrostjo deformacije med $1 \times 10^{-3} \mathrm{~s}^{-1}$ in $3 \times 10^{-2} \mathrm{~s}^{-1}$ ter jih okarakterizirali z modificiranima enačbama Hooka in Grosmana. Preizkus vlečenja so izvajali na štiri različne načine v območjih od ekvivalentne dvo-osne do ravninske deformacije. Ugotavljali so vpliv temperature, deformacijskega razmerja, dobljenega pri testu vlečenja (višine deformirane polkrogle), tlaka preoblikovanja, porazdelitve debeline in kavitacije. Ugotavljajo še, da sta stopnja deformacije in tlak preoblikovanja bolj odvisna od geometrije orodja kot od temperature. Z naraščanjem temperature in tlaka vlečenja, se občutljivost na geometrijsko razmerje orodja povečuje bolj kot na temperaturo preizkusa. Poviševanje temperature preizkusa vlečenja izboljšuje porazdelitev debeline preoblikovanega preizkušanca, toda to lahko privede do povečane kavitacije. Rezultati diagrama omejitev preoblikovanja kažejo pomemben raztros podatkov glede na deformacijo, pri kateri pride do odpovedi (porušitve) materiala. To kaže na to, da mej preoblikovanja superplastične zlitine 2A97 ne moremo predstaviti z enostavnim diagramom preoblikovanja, zato bodo morali avtorji izvesti še dodatne analize meritev interne kavitacije.

Ključne besede: superplastičnost, Al-Li zlitina 2A97, omejitve preoblikovanja, kavitacija

\section{INTRODUCTION}

Nowadays, weight reduction is a crucial aspect of aircraft design. ${ }^{1}$ For most transport aircraft, including the Airbus A380, aluminum alloys account for about $60 \%$ of the structural weight. ${ }^{2}$ The density of aluminum (Al) alloys can be lowered by $3 \%$ with a 1 w/\% addition of lithium $(\mathrm{Li}) .^{3}$ There is a notable trend toward using aluminum-lithium (Al-Li) alloys to replace conventional aluminum alloys as structural materials. This is due to their relatively low density, high elastic modulus, high specific strength and other good properties. ${ }^{4}$ However, there are plenty of difficulties during cold forming, such as low formability, high notch sensitivity and crack formation. The superplastic forming (SPF) process opens up a new direction for solving the complex forming of Al-Li alloy sheet. ${ }^{5}$

*Corresponding author's e-mail: rxp33@ustb.edu.cn (Xueping Ren)
This work is primarily concerned with the superplastic forming of specially processed 2A97 Al-Li alloys for SPF. As a novel damage-tolerant alloy newly developed in China, 2A97 exhibits excellent fracture toughness and malleability, in addition to the benefits of normal Al-Li alloys. The 2A97 Al-Li alloy has attracted much research interest as an alloy with moderate strength, corrosion resistance and weldability, ${ }^{5-16}$ which has opened up potential applications in the aerospace, aviation and military industries. However, less research work has been carried out on the superplastic forming properties of 2A97 Al-Li alloy. Accurately predicting the fracture behavior of the 2A97 alloy in SPF has important significance for engineering applications.

The forming limit is an important performance index for the fracture behavior of sheet metal forming, and reflects the maximum amount of deformation that can be reached before the plastic deformation of the material is unstable during the forming process. ${ }^{17}$ The Forming Limit Diagram (FLD), is a band region or curve formed 
by the local instability limit of sheet metal under different strain paths, which can fully reflect the local forming limit of sheet metal under unidirectional and biaxial tension stress. ${ }^{18-20}$ It is an essential tool to assess the sheet-metal formability in metal-forming operations..$^{21,22}$ The FLD lays the foundation for a qualitative and quantitative study of the local forming properties of sheet metal. At present, FLD is often used in the finite-element method (FEM) simulation in most of the sheet forming.

To better predict the fracture behavior of 2A97 alloy sheet during the SPF process, it is necessary to perform a comprehensive study of the tensile properties, forming limit, and cavitation evolution. Cavitation occurs during the superplastic deformation of high-strength aluminum alloys, resulting in the development of small intergranular voids during straining. ${ }^{23}$ The cavities formed during superplastic forming can induce premature failure of superplastic materials during processing, ${ }^{24-26}$ and affect the subsequent service properties (ambient temperature tensile and fatigue) of superplastically formed parts. $^{27}$ Therefore, FLD is not the only criterion for evaluating superplastic-forming performance. It is necessary to perform a comprehensive study of the cavitation behavior and FLD to establish the practical criteria for evaluating the superplastic forming limit of 2A97 alloy sheet.

In this paper, experiments were conducted on 2A97 Al-Li sheet alloys using both the uniaxial tensile test and biaxial tension bulge test at $350{ }^{\circ} \mathrm{C}-430{ }^{\circ} \mathrm{C}$. The FLD was determined from specimens that were deformed by a pneumatic bulge test with tool ratios of $1: 1,4: 3,2: 1$, and $8: 3$. The shape of the forming-limit curves was found to be different from that of traditional room-temperature forming-limit curves. In order to determine the influence of temperature on cavitation, samples from the formed parts were studied using optical microscopy.

\section{MATERIALS AND EXPERIMENTAL PROCEDURE}

\subsection{Materials}

The material in this paper is an Al-Cu-Li alloy supplied by Southwest Aluminum (Group) Co., Ltd.,

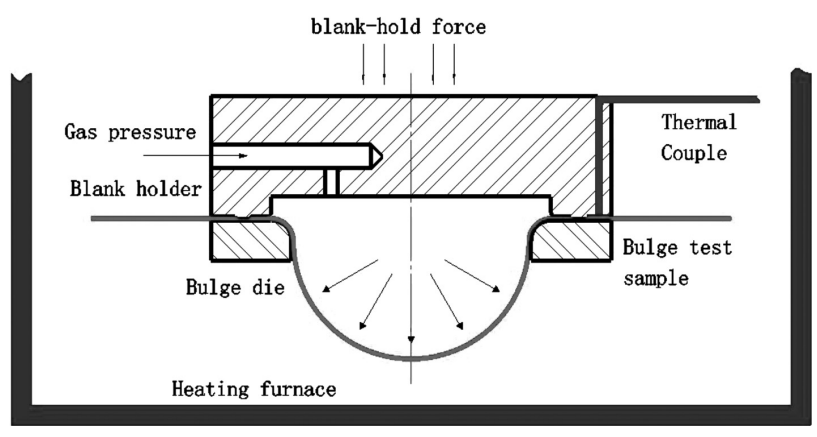

Figure 1: Schematic diagram of bulge testing apparatus
China, referred to as 2A97 alloy. The nominal chemical composition of the sheet was $\mathrm{Al}-3.8 \mathrm{Cu}-1.4 \mathrm{Li}-0.5 \mathrm{Mg}-$ $0.5 \mathrm{Zn}-0.3 \mathrm{Mn}-0.2 \mathrm{Ti}-0.2 \mathrm{Si}-0.1 \mathrm{Zr}-0.06 \mathrm{Fe}-0.006 \mathrm{Be}$ $(w / \%)$. The material used is 2.5 -mm-thick warm-rolled plates, and was specifically thermomechanically treated for superplastic forming. After casting and homogenizing, the alloy is hot rolled to $25 \mathrm{~mm}$ in thickness to break down the as-cast structure. The material is solution treated at $520{ }^{\circ} \mathrm{C}$ for $2 \mathrm{~h}$ to take most of the copper into solid solution, and aged at $400{ }^{\circ} \mathrm{C}$ for $48 \mathrm{~h}$ to obtain the uniform distribution and a larger volume fraction of the second-phase particles. ${ }^{5}$ And then the plate is warm rolled to the as-received state with intermediate annealing to avoid rolling cracking. ${ }^{12}$

\subsection{Experimental procedure}

\subsubsection{Tensile test}

The tensile tests were conducted on a SK10-70×300 universal testing machine equipped with a three-zone heating furnace with temperature control accuracy of $\pm 3{ }^{\circ} \mathrm{C}$. Four K-type thermocouples were used to monitor the temperature: three for the furnace and one for the specimen. Tests were initiated following equilibration of the testing temperature and samples were held at the target temperature for $30 \mathrm{~min}$ prior to tension. The tensile experiments were carried out at temperatures of $350-430{ }^{\circ} \mathrm{C}$ with an initial strain rate ranging from $1 \times 10^{-3} \mathrm{~s}^{-1}$ to $3 \times 10^{-2} \mathrm{~s}^{-1}$ without any atmosphere protection. The dog-bone tensile samples were cut along the $\mathrm{RD}$ with a gauge length of $10 \mathrm{~mm}$ and $6 \mathrm{~mm}$ in width.

\subsubsection{Bulge forming}

The schematic diagram of the bulge forming die is shown in Figure 1. It was fixed within a 300-ton SPF press and equipped with a heating furnace of $50 \mathrm{~kW}$. Integral heating was adopted for superplastic forming heating. The forming temperature was maintained by heaters arranged on four sides of the furnace. The holes were reserved in the upper die shown in Figure 1 so that the thermocouple can be placed in to monitor the temperature of the sample in real time. The edge of the sheet was pressed by the blank holder and the lower die to ensure sealing. Samples were pre-heated for $30 \mathrm{~min}$ to achieve the target temperature before the press was closed and the blank sealed between the lower and upper die halves. The loading rate of the gas pressure is 0.04 $\mathrm{MPa} / \mathrm{min}$. Circular samples with a diameter of $100 \mathrm{~mm}$ for the bulging experiment were fabricated by laser cutting from the as-received sheet.

The circular grid patterns with a diameter of $2 \mathrm{~mm}$ were electrochemically etched on the surface of the samples prior to the forming. Both sides of the blank and the inner wall of the die were coated with a SPF lubricant containing boron nitride. The lubricant was received in water-based suspensions to allow spraying applications. The lubricant was allowed to dry in air, leaving only the solid components on the surface. The lubricant 


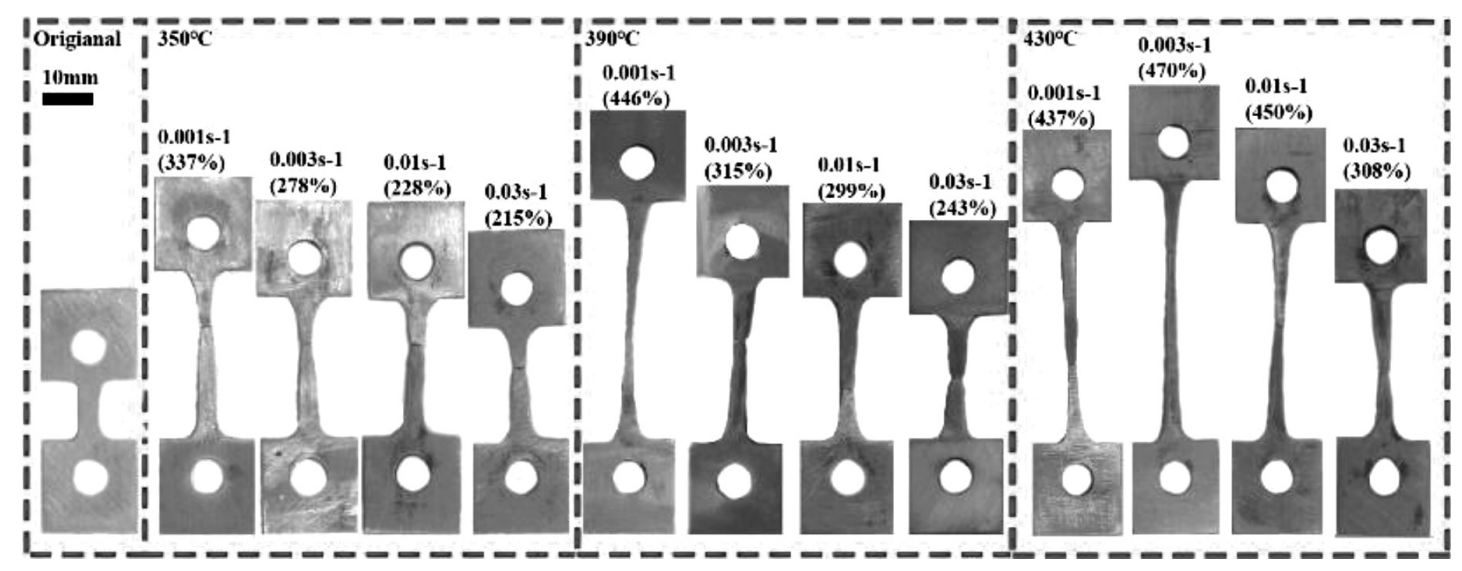

Figure 2: Macrophotograph of some specimens before and after the tensile test

can reduce the oxidation of the sheet in the forming process, effectively preventing the sheet from sticking to the die, and playing the role of typing agent in the process of parts extraction. In the experiment, the long axis of the die is parallel to the rolling direction of the sample.

In actual production, the material deformation in sheet-metal forming processes is often not in the equibiaxial stress state. It requires different die geometries to obtain different stress and strain states. One set of lower dies, with a length of $60 \mathrm{~mm}$ and different widths of (60, 45, 30, and 22.5) $\mathrm{mm}$ were designed, in which each die represents one strain path on the FLD. The entry radius of $5 \mathrm{~mm}$ is designed on the lower die to prevent the pattern from breaking due to local thinning. All the test samples were formed until failure.

\section{RESULTS AND DISSCUSSION}

\subsection{Constitutive model}

Figure 2 shows the specimens before and after the superplastic tensile test. It can be seen that the elongation and the section shrinkage of the specimens increase significantly with decreasing strain rates and increasing deformation temperature. The maximum elongation of the 2A97 alloy at $350{ }^{\circ} \mathrm{C}, 390{ }^{\circ} \mathrm{C}$, and $430{ }^{\circ} \mathrm{C}$ was $337 \%, 446 \%$, and $470 \%$, respectively. The optimum strain rate decreases with the increase of the temperature.

The constitutive equation is a mathematical model that describes the flow stress during the deformation process. The constitutive model is mainly divided into two categories. ${ }^{28}$ The first group of the model directly describes the influence of deformation conditions such as the temperature and strain rate on the flow stress. These models usually do not take into account the deformation history. They describe correctly the flow stress in cases when strain hardening is the dominant factor that determines the state of the materials. The model parameters mainly include the work-hardening coefficient, the strain-rate sensitivity index and the temperature. The second group embraces models in which the deformation history affects the internal state of a material, determined primarily by its structure, ${ }^{29}$ and in which the actual response of the material to the deformation conditions depends on its internal state. Because the superplasticity experiment temperature is low and the original structure is a lath structure, the hardening stage accounts for a relatively high proportion in the tensile curve, so the first group of the model is adopted in this paper. The Grossman equation in the first model can describe three states of deformation: work hardening, softening, and flow-stress steady state. The tensile process can be divided into two ordinal phases: elastic deformation phase and ductile deformation phase. The modified Hooke equation and the Grossman equation describe the elastic and plastic stages, respectively, as shown in Equations (1) and (2).

elastic deformation phase:

$$
\sigma_{\mathrm{e}}=E(T, \dot{\varepsilon}) \varepsilon
$$

ductile deformation phase:

$$
\sigma_{\mathrm{p}}=K \varepsilon^{n} \dot{\varepsilon}^{m} \varepsilon^{B \varepsilon}
$$

Where $\sigma_{\mathrm{e}}$ and $\sigma_{\mathrm{p}}$ represent the flow stress in the elastic and plastic stages, respectively, $\mathrm{E}$ is the elastic modulus, $K$ is the material coefficient, $m$ is strain-rate-a sensitive coefficient, $n$ is a strain-hardening coefficient, and $B$ is a strain-softening coefficient.

The elastic modulus is obtained by calculating the slope of the stress-strain curve in the elastic deformation stage. It was found that the E-value is different under different strain rates and temperatures. The relationship between the elastic modulus and the temperature and strain rate is obtained using the least-squares method, shown as Equation (3):

$E=11053.589-18.206 T+241191 \dot{\varepsilon}-256.677 T \dot{\varepsilon}+$

$+0.006 T^{2}-1289064 \dot{\varepsilon}^{2}$

Based on the unidirectional tension data of the 2A97 Al-Li superplastic alloy, the differential evolution method was used for a regression analysis of Equation (2). It was found that the strain rate had little effect on $K$ and $B$ in the plastic stage, so it only considered the effect 
of temperature on them here. The relationship curves between $K, B, n, m$ and $T, \dot{\varepsilon}$ are established. The regression analysis is carried out by using the least-squares method and MATLAB, and the following Equations (4), (5), (6), and (7) are obtained.

$$
\begin{gathered}
K=-35422.566+10805.034\left(\frac{T}{100}\right)-812.792\left(\frac{T}{100}\right)^{2} \\
B=70.307-21.336\left(\frac{T}{100}\right)-1.591\left(\frac{T}{100}\right)^{2} \\
m=-4.211+1.2526\left(\frac{T}{100}\right)-0.086\left(\frac{T}{100}\right)^{2} \\
n=9.660-2.632\left(\frac{T}{100}\right)+6.415 \dot{\varepsilon}+4.473\left(\frac{T}{100}\right) \dot{\varepsilon}- \\
-0.185\left(\frac{T}{100}\right)^{2}-1017.642 \dot{\varepsilon}^{2}
\end{gathered}
$$
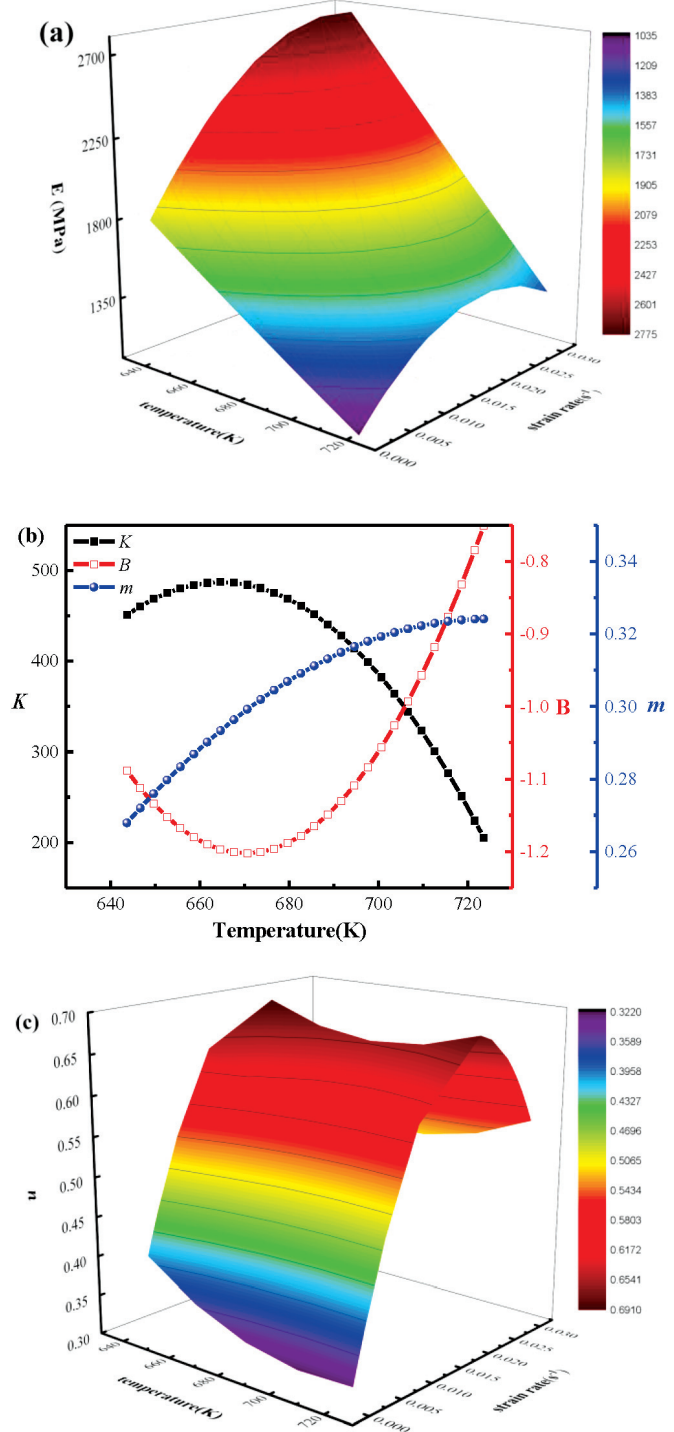

Figure 3: Diagrams of the relationships between the parameters, the temperature and the strain rate
Figure 3 depicts the relationships between the parameters of the 2A97 superplastic alloy and the temperature and strain rate. Seen from Figure 3a, the elastic modulus decreases with the increase of the temperature and the decrease of the strain rate. The effect of temperature on elastic modulus is greater than that of the strain rate. With an increase of the temperature, the strain-rate sensitivity index increases, the strain-softening factor decreases first and then increases, and the material coefficient increases first and then decreases, as seen from Figure 3b. The strain-hardening factor decreases with an increase of the temperature and a decrease of the strain rate, as shown in Figure 3c.

The comparison between the experimental and fitted curves under different strain rates at $410{ }^{\circ} \mathrm{C}$ is shown in Figure 4. The theoretical stress-strain curves are in good agreement with the actual ones. It can be seen that the flow curve could be divided into three stages in the tensile test. At the first stage, the flow stress increases with the increase of the strain. At the second stage, the curves of different strain rates can be divided into two types: softening and steady state. Within the range of high strain rates $\left(>0.001 \mathrm{~s}^{-1}\right)$, the flow stress tends to be stable during the deformation process, indicating a dynamic balance between strain hardening and softening. In the range of low strain rate $\left(<0.001 \mathrm{~s}^{-1}\right)$, the flow stress decreases continuously with the strain. The strain hardening behavior was mainly caused by sub-grain growth. Since the stacking-fault energy of an aluminum alloy is relatively low, the softening behavior might be attributed to two factors: the decreasing true strain rate and the dynamic recrystallization. ${ }^{30}$ At the third stage, the flow stress rapidly decreases, and the localized necking occurs at the specimens until fracture. The fitting curve accurately reveals this flow behavior. Therefore, the constitutive equation can represent the flow stress of the 2A97 alloy for the temperature range of $350-430{ }^{\circ} \mathrm{C}$ with the strain rate of $0.001 \mathrm{~s}^{-1}$ to $0.03 \mathrm{~s}^{-1}$, and could be used for the theoretical computation of the forming limits.

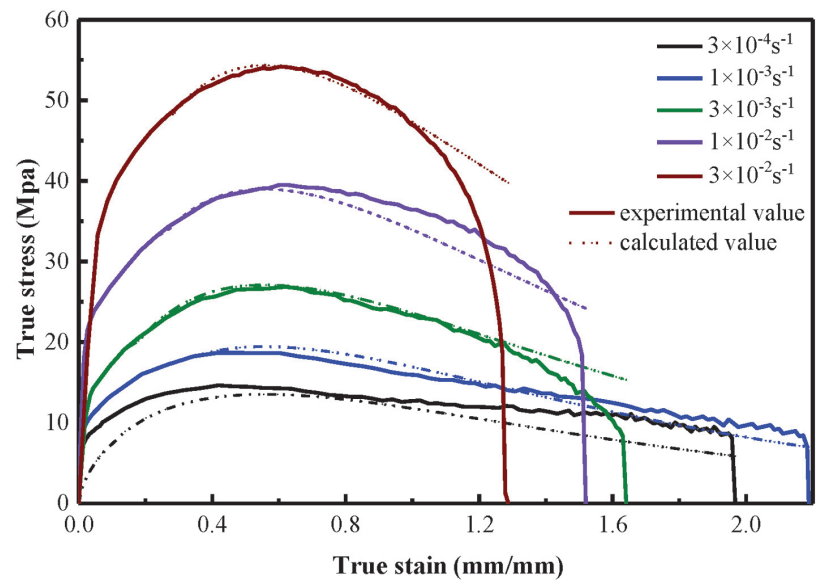

Figure 4: Comparison between the experimental and fitted curves under different strain rates at $410{ }^{\circ} \mathrm{C}$ 


\subsection{Forming-Limit diagram}

In order to establish the FLD of the superplastic 2A97 Al-Li alloy, the superplastic bulging tests with different die ratios were carried out at $(350,390$, and 430) ${ }^{\circ} \mathrm{C}$. According to the constitutive equation mentioned above, the forming process was fitted by ANSYS software, and the bulging pressure rate corresponding to the initial strain rate of $1 \times 10^{-3} \mathrm{~s}^{-1}$ was $0.04 \mathrm{MPa} / \mathrm{min}$. All the bulging experiments were carried out until the specimens failed. Figure 5 shows the macroscopic view of the specimens after bulging with different dies ratios at $390{ }^{\circ} \mathrm{C}$.

The forming pressure and peak height of the bulge samples deformed at different temperatures with different tool aspect ratios are plotted in Figures $\mathbf{6 a}$ and $\mathbf{6 b}$. It can be seen from Figure 6a that increasing temperature generally reduces the forming pressure and increases the dome height. When the die ratio is $4: 3$, the forming pressure is $3.4 \mathrm{MPa}$ and the dome height is $34.12 \mathrm{~mm}$ at $350{ }^{\circ} \mathrm{C}$. While the temperature increase to $430{ }^{\circ} \mathrm{C}$, the forming pressure and dome height are $1.96 \mathrm{MPa}$ and $35 \mathrm{~mm}$, respectively. The effect of temperature on the forming pressure is greater than that on the bulging height. It can be concluded from Figure 6b that the forming pressure increases and the bulging height decreases with the increase of the tool aspect ratio at the same temperature. At $390{ }^{\circ} \mathrm{C}$, the forming pressure is only $1.66 \mathrm{MPa}$ and the dome height is $40.2 \mathrm{~mm}$ with the die ratio of $1: 1$. When the die ratio is increased to $8: 3$, the forming pressure is increased to $4 \mathrm{MPa}$ and the dome height is $26.96 \mathrm{~mm}$. The forming pressure and dome height appear to be sensitive to the die ratios. The thickness distribution is an important index to measure the uniformity of the superplastic bulging. In order to investigate the thickness distribution of deformed parts, specimens were cut along the 0 and $45^{\circ}$ section. A thickness gauge was used to measure the thickness along the cross-section and thickness reduction was calculated

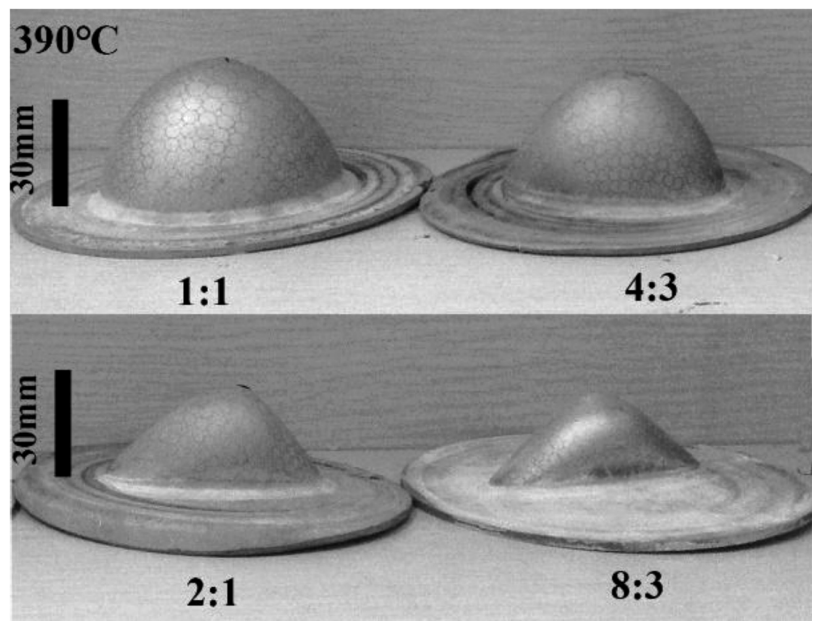

Figure 5: Superplastic bulge specimens with different die ratios at $390{ }^{\circ} \mathrm{C}$ and plotted as a function of the location along the cross-section, as shown in Figure 6c. It shows that the thickness distribution of the parts after superplastic bulging at $(350,390$ and 430$){ }^{\circ} \mathrm{C}$ with the die ratio of $1: 1$. The thickness reduction appears to decrease with increasing temperature. The maximum thickness reduction at $(350,390$ and 430$){ }^{\circ} \mathrm{C}$ are $(86.3,85$, and 84.1) \%, respectively.

In order to calculate the superplastic forming limit of the 2A97 Al-Li alloy, the grids near the fracture zone of the deformed specimen were selected to measure with the single-grid method. The principal and secondary strains of each grid were calculated and the FLD was drawn. Figure 7a shows the FLD of the 2A97 Al-Li alloy with different die ratios at $390{ }^{\circ} \mathrm{C}$. It can be seen that the data points obtained under different die ratios are
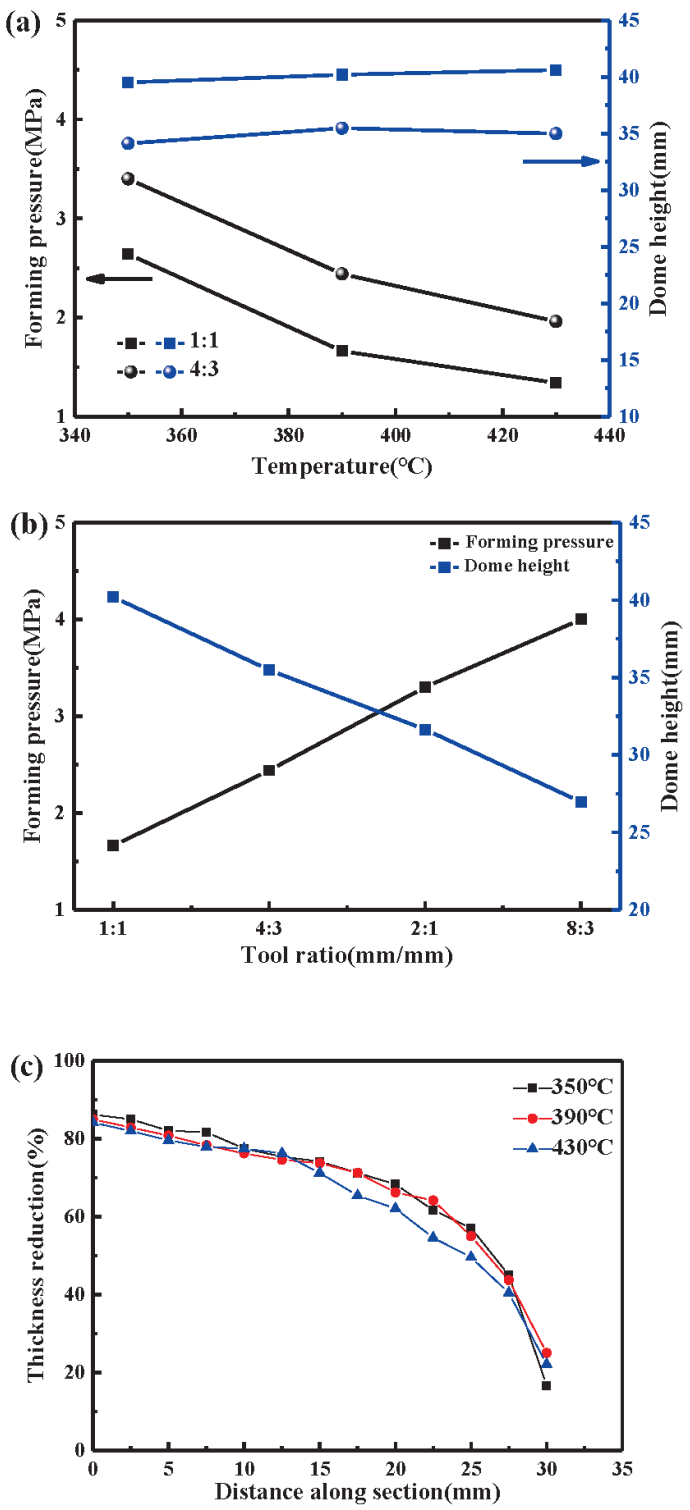

Figure 6: Forming pressure and dome height plotted as a function of: a) temperature and b) tool ratio for tests performed at $390{ }^{\circ} \mathrm{C}, \mathrm{c}$ ) thickness distribution plotted as a function of distance along the section 
scattered, and the material is sensitive to the stress state. Figure 7b shows the FLD of 2A97 alloy at different temperatures. The deformation necking zone of the material is shown in the shadows of the figure. The safety zone is below the necking zone and the failure zone is above the necking zone. It can be seen from Figure $\mathbf{7 b}$ that the forming limit at $390{ }^{\circ} \mathrm{C}$ is obviously better than that at $350{ }^{\circ} \mathrm{C}$ and $430{ }^{\circ} \mathrm{C}$. This is consistent with the tensile properties at this strain rate.

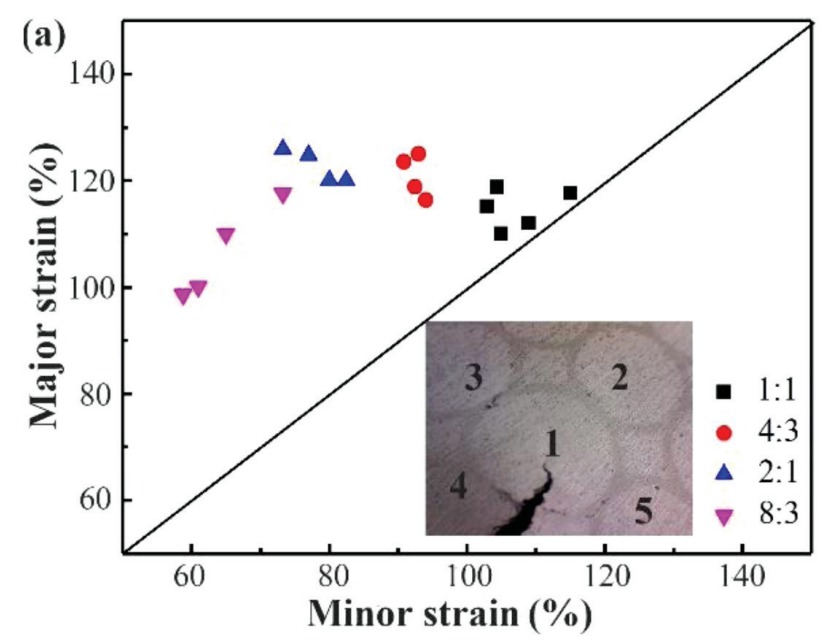

\subsection{Cavitation}

The intrinsic problem with the present methods of superplastic forming is the nonuniform thickness observed in the formed components. Cavity formation is another disadvantage associated with superplasticity. Thickness variation and cavitation affect the mechanical properties of the superplastically formed components. ${ }^{23}$ To measure the extent of cavitation in the deformed regions, samples were extracted from the formed parts and investigated with optical microscopy. The cavity

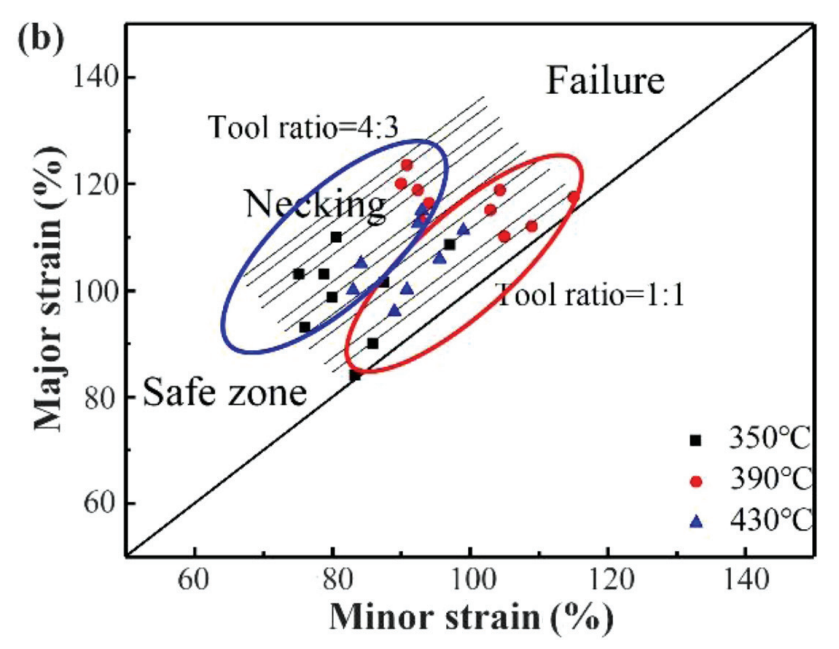

Figure 7: Forming-limit diagram of 2 A97 alloy: a) at $390{ }^{\circ} \mathrm{C}$ with different tool ratios, b) at different temperatures with the tool ratios of $1: 1$ and $4: 3$
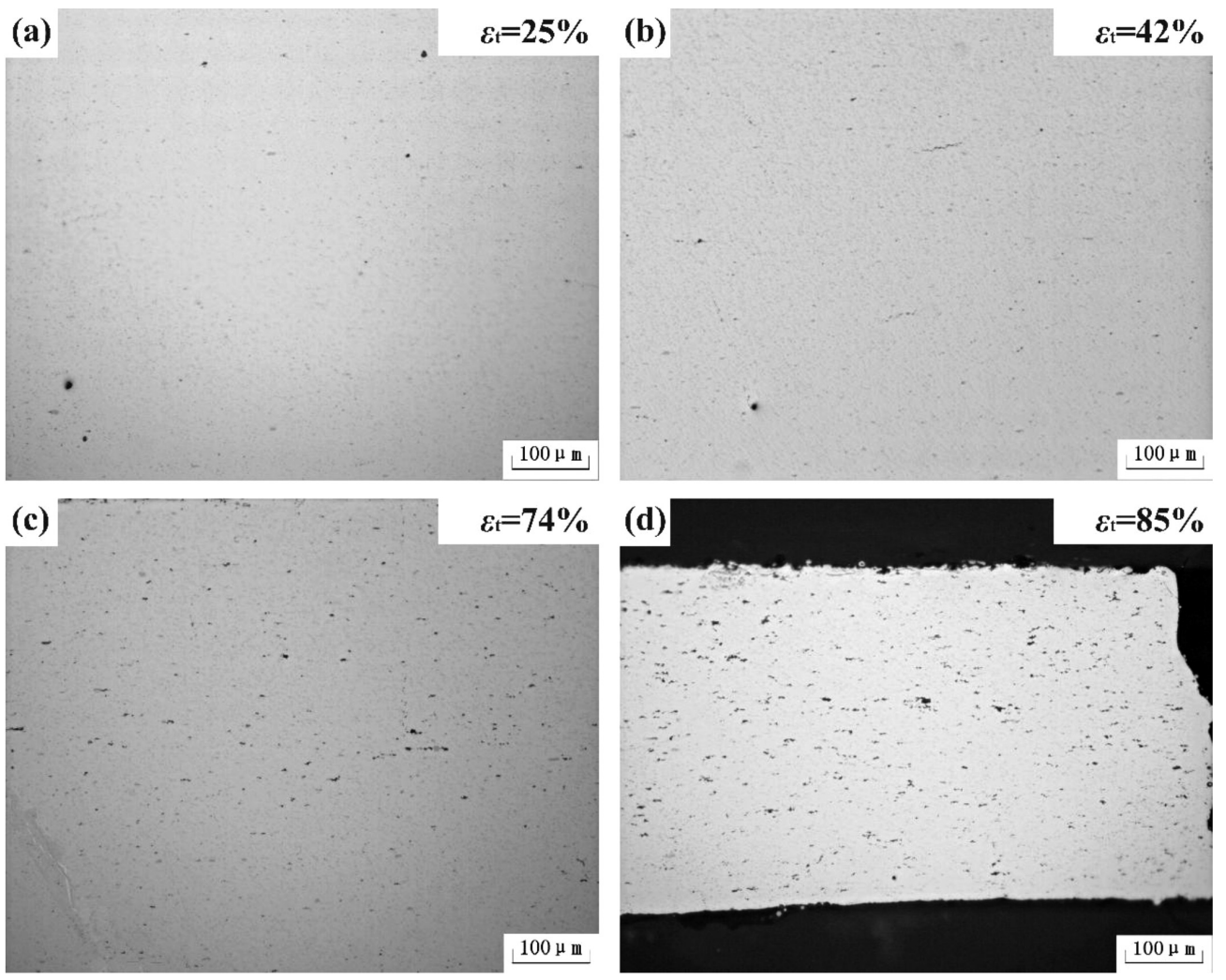

Figure 8: Optical micrographs showing the cavitation of $2 \mathrm{~A} 97$ deformed at $390{ }^{\circ} \mathrm{Cwith}$ a die ratio of $1: 1$ corresponding to different thinning ratios (rolling direction is horizontal) 


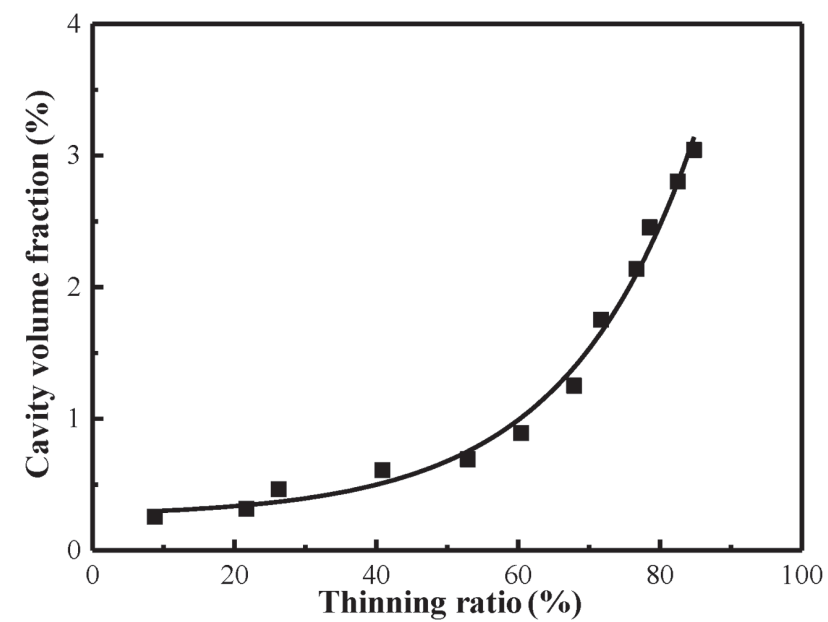

Figure 9: Cavitation volume fraction plotted as a function of thinning ratio for equi-biaxial tension at $390{ }^{\circ} \mathrm{C}$

distribution at the different thinning ratios of the deformed part at $390{ }^{\circ} \mathrm{C}$ with a die ratio of $1: 1$ is shown in Figure 8. It can be concluded that with the increase of the thinning ratio, $\varepsilon_{t}$, the degree of cavitation increases. Where the thinning ratio is $25 \%$, there are few voids; the number of voids does not increase significantly at the thinning ratio of $42 \%$. The density of the cavities increases significantly where the thinning rate reaches $74 \%$. Some cavities interconnect and aggregate at the bulging rupture $\left(\varepsilon_{\mathrm{t}}=85 \%\right)$. There are not only a large number of large cavities but also a large number of small voids in this region, indicating that cavity nucleation and growth coexist in the superplastic bulging process.

In order to quantitatively evaluate the cavitation behavior of the 2A97 Al-Li alloy after superplastic bulging, the fraction of cavities is calculated. The volume fraction of cavities, which can be approximated as the area fraction of cavities, is the sum of the products of the population and the size of the individual cavities. ${ }^{18}$ Two-dimensional measurements of cavities on the cutting planes were conducted via computer imaging using the method discussed in ${ }^{31}$. Figure 9 depicts the variation of the cavity area fraction with the thinning ratio for equi-biaxial tension at $390{ }^{\circ} \mathrm{C}$. As can be seen from Figure 9, the cavity area fraction increases exponentially with the thinning ratio. When $\varepsilon_{\mathrm{t}}<40 \%$, the cavity area fraction increases slowly with the thinning ratio. While $\varepsilon_{\mathrm{t}}>40 \%$, the cavity area fraction increases rapidly with deformation. This clearly shows that new cavities were continuously nucleated with the increasing strain. The increase of strain not only promotes the rapid growth of cavities generated by low deformation, but also promotes the nucleation of new cavities. It is believed that cavity nucleation during superplastic deformation (SPD) is caused by the stress concentration at a particle or ledge in the grain boundary produced by grain-boundary sliding (GBS). ${ }^{23,32}$ Based on the existing models, it appears that cavity nucleation is a result of the stress concentration arising from incomplete accommodations of the GBS. It can be assumed that both the cavity growth and the nucleation of new cavities contributed to the increasing cavity volume fraction. So, when the thinning ratio reaches a certain degree, the cavity area fraction will increase rapidly with the strain. It confirms that cavity growth is essentially strain-controlled during superplastic deformation. ${ }^{33}$

The effect of temperature on cavitation is presented in Figure 10, from samples with a thinning ratio of $\approx 85 \%$ for the three test temperatures. Clearly, the specimens deformed at the optimum superplastic temperature of $390{ }^{\circ} \mathrm{C}$ exhibited the least cavitation. An increasing or decreasing temperature resulted in an increase in the cavity volume fraction for a given strain. At the lowest test temperature of $350{ }^{\circ} \mathrm{C}$, the size of cavity is small, but the number is large. This may be due to the stress concentration caused by insufficient GBS at low temperature, which promotes the cavity nucleation. At $430{ }^{\circ} \mathrm{C}$, the significant cavity coalescence and linkage lead to an increase in the volume fraction of the cavities. The deformed sample exhibits the highest ratio of large-size cavities and the cavity volume fraction. This is attributed to a more intense grain growth during higher-temperature exposure. In addition, the increase in the grain size results in an increase in the cavitation tendency in the superplastic materials. ${ }^{34}$ Therefore, the size and volume fraction of the cavities of 2A97 increase with increasing temperature from $390{ }^{\circ} \mathrm{C}$ to $430{ }^{\circ} \mathrm{C}$. The large-size cavities are most harmful to the overall properties of the superplastically formed components and healed with difficulty by subsequent treatment. Therefore, the SPF of
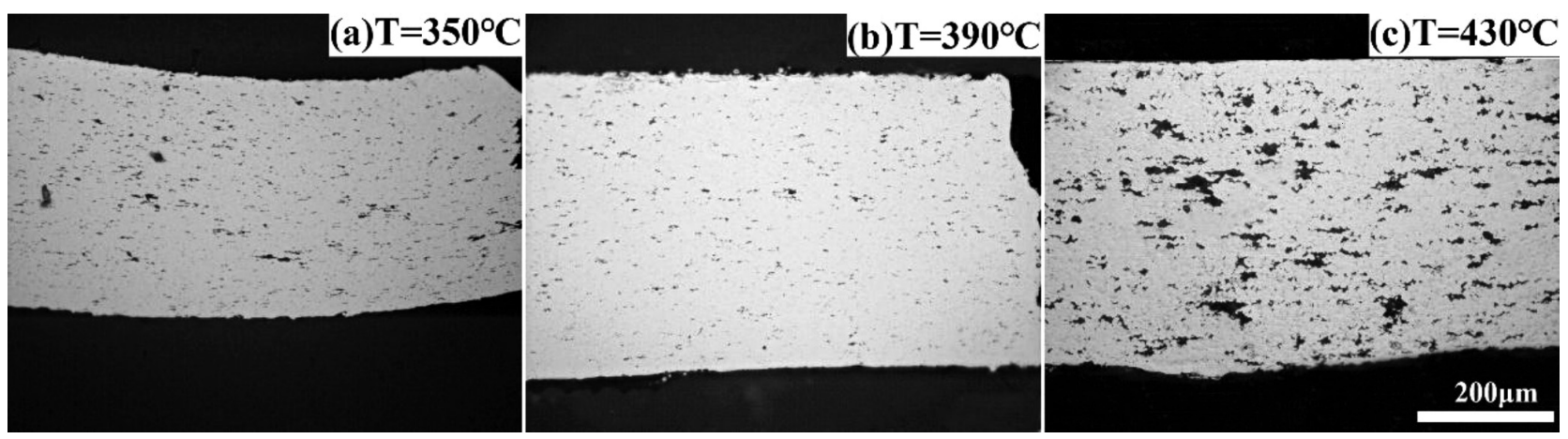

Figure 10: Effect of temperature on cavitation of $2 \mathrm{~A} 97$ for $\varepsilon_{\mathrm{t}}=85 \%$ (rolling direction is horizontal) 
2A97 at lower temperatures is a practical requirement, which at high temperature should be avoided.

The results of the bulge test in this paper show significant scatter in terms of the forming-limit data. This is closely related to the accumulated damage and the final failure mode of high-strength aluminum alloy, in which cavity coalescence eventually induces failure. ${ }^{23}$ The nucleation, growth and aggregation of cavities or voids occur during superplastic deformation. The damage accumulation in the superplastic forming process is a complicated, dynamic process in which a wide variety of cavity formations can occur. The low-flow stresses in the SPF make it possible for the material to continue to form even though the material contains significant cavitation. ${ }^{19}$ The strain values obtained by measuring the grids near the fracture zone cannot reflect the real damage of the material. Therefore, the FLD is not a perfect method for evaluating the forming performance of superplastic forming. The true criterion for material failure should be considered to be when the material has attained a certain extent of cavitation, rather than when the material ruptures.

\section{SUMMARY AND CONCLUSIONS}

This work focuses on the failure modes of the superplastic 2A97 alloy rolled sheet and considers the metrics necessary to establish practical superplastic forming limits. The superplastic tensile behavior, forming limit, and cavitation are studied in this paper. Some conclusions are summarized as follows:

1) The flow stresses of the 2A97 alloy in the temperature range $350-430{ }^{\circ} \mathrm{C}$ with an initial strain rate ranging from $1 \times 10^{-3} \mathrm{~s}^{-1}$ to $3 \times 10^{-2} \mathrm{~s}^{-1}$, are accurately characterized by the modified Hooke equation and Grossman equation. The theoretical stress-strain curves are in good agreement with the actual ones.

2) Results of the bulge tests show significant scatter in terms of failure strain. The FLD is not a perfect method for evaluating the superplastic forming performance of the 2A97 Al-Li alloy. But the dome height and thickness reduction provide useful and quantifiable data that may be applicable to establish a suitable criterion for determining the practical forming limits when coupled with proper consideration of the role of cavitation. Dome height and forming pressure appear to be more sensitive to tool ratio than temperature.

3) The cavity volume fraction should be specified as the forming-limit index of the 2A97 alloy. Therefore, it is necessary to study the cavitation during SPF. The evolution of cavity volume is due to both nucleation and the growth of cavities. Cavity growth is essentially strain-controlled during superplastic deformation.

\section{Acknowledgment}

This research was carried out with funding from the National Basic Research Program of China (973 Program, Grant No. 2011CB012804) and the National Natural Science Funds of China (Grant No. 51605458,51334006,51405457). The authors would like to acknowledge assistance of these programs for the financial support.

\section{REFERENCES}

${ }^{1}$ J. J. Lee, Can we accelerate the improvement of energy efficiency in aircraft systems?, Energy Convers. Manag. 51 (2010) 1, 189-196, doi:10.1016/j.enconman.2009.09.011

${ }^{2}$ N. E. Prasad, A. Gokhale, R. J. H. Wanhill, Aluminum-Lithium Alloys: Processing, Properties, and Applications, 2014, 27

${ }^{3}$ E. A. Starke, J. T. Staley, Application of modern aluminum alloys to aircraft, Prog. Aerosp. Sci. 32 (1996) 2, 131-172, doi:10.1016/ 0376-0421(95)00004-6

${ }^{4}$ V. Rajendran, S. M. Kumaran, T. Jayakumar, P. Palanichamy, P. Shankar, B. Raj, Microstructure and ultrasonic behaviour on thermal heat-treated Al-Li 8090 alloy, J. Alloy. Compd. 478 (2009) 1, 147-153, doi:10.1016/j.jallcom.2008.11.067

${ }^{5}$ X. Zhang, L. Xie, L. Ye, P. Zhang, Effect of aging treatment on grain refinement and superplasticity of 2A97 aluminum-lithium alloy, Heat Treat. Met. 39 (2014) 2, 88-93, doi:10.13251/j.issn.02546051.2014.02.025

${ }^{6}$ Z. S. Yuan, Z. Lu, Y. H. Xie, S. L. Dai, C. S. Liu, Effects of RRA Treatments on Microstructures and Properties of a New High-strength Aluminum-Lithium Alloy-2A97, Chinese J. Aeronaut. 20 (2007) 2, 187-192, doi:10.1016/s1000-9361(07)60031-4

${ }^{7}$ L. Yi, Z. Q. Zheng, H. Ye, H. F. Zhang, Effects of heat treatment process on tensile and corrosion properties of 2A97 al-li alloy, Chinese J. Nonferrous Met. 22 (2012) 8, 2181-2186, doi:10.1007/s11783-011-0280-Z

${ }^{8}$ B. Fu, G. Qin, X. Meng, Y. Ji, Y. Zou, Z. Lei, Microstructure and mechanical properties of newly developed aluminum-lithium alloy 2A97 welded by fiber laser, Mater. Sci. Eng. A 617 (2014) 1-11, doi:10.1016/j.msea.2014.08.038

${ }^{9}$ C. Gao, Y. Luan, J. C. Yu, Y. Ma, Effect of thermo-mechanical treatment process on microstructure and mechanical properties of 2A97 Al-Li alloy, T. Nonferrous Metal. Soc. 24 (2014) 7, 2196-2202, doi:10.1016/s1003-6326(14)63332-x

${ }^{10}$ C. Gao, R. Gao, Y. Ma, Microstructure and mechanical properties of friction spot welding aluminium-lithium 2A97 alloy, Mater. Des. 83 (2015), 719-727, doi:10.1016/j.matdes.2015.06.013

${ }^{11}$ J. Bi, Y. L. Zhang, N. Zhang, H. L. Hou, Superplastic deformation law and constitutive equation of 2a97 al-li alloy, J. Netshape Forming Eng. 7 (2015) 2, 41-45, doi:10.3969/j.issn.1674-6457.2015.02.007

${ }^{12}$ L. Li, L.Y. Ye, Y. L. Deng, X. M. Zhang, S. B. Zeng, D. X. Sun, Z. J. Shan, Effects of intermediate annealing on grain refinement and superplasticity of 2A97 aluminum-lithium alloy, Chinese J. Nonferrous Met. 25 (2015) 1, 36-42, doi:10.19476/j.ysxb.1004. 0609.2015.01.006

${ }^{13}$ H. Y. Chen, L. Fu, P. Liang, Microstructure, texture and mechanical properties of friction stir welded butt joints of 2A97 Al Li alloy ultra-thin sheets, J. Alloy. Compd. 692 (2017), 155-169, doi:10.1016/j.jallcom.2016.08.330

${ }^{14}$ H. Chen, L. Fu, P. Liang, F. Liu, Defect features, texture and mechanical properties of friction stir welded lap joints of 2A97 Al-Li alloy thin sheets, Mater. Charact. 125 (2017), 160-173, doi:10.1016/ j.matchar.2017.01.038

${ }^{15}$ J. Ning, L. Zhang, Q. Bai, X. Yin, J. Niu, J. Zhang, Comparison of the microstructure and mechanical performance of 2A97 Al-Li alloy 
joints between autogenous and non-autogenous laser welding, Mater. Des. 120 (2017), 144-156, doi:10.1016/j.matdes.2017.02.003

${ }^{16}$ B. Fu, G. Qin, X. Meng, Y. Ji, Y. Zou, Z. Lei, Microstructure and mechanical properties of newly developed aluminum-lithium alloy 2A97 welded by fiber laser, Mater. Sci. Eng. A 617 (2014) 1-11, doi:10.1016/j.msea.2014.08.038

${ }^{17}$ J. He, Z. C. Xia, X. Zhu, D. Zeng, S. Li, Sheet metal forming limits under stretch-bending with anisotropic hardening, Int. J. Mech. Sci. 75 (2013) 244-256, doi:10.1016/j.ijmecsci.2013.07.007

${ }^{18}$ Y. Luo, C. Miller, G. Luckey, P. Friedman, Y. Peng, On Practical Forming Limits in Superplastic Forming of Aluminum Sheet, J. Mater. Eng. Perform. 16 (2007) 3, 274-283, doi:10.1007/s11665007-9048-9

${ }^{19}$ Y. Luo, D. Li, Y. Peng, Formability and cavitation behavior of superplastic AA5083 aluminum alloy under biaxial tension, T. Nonferrous Metal. Soc. 16 (2006) s3, 1630-1633, doi:10.1021/ ja104264v

${ }^{20}$ X. Chu, L. Leotoing, D. Guines, E. Ragneau, Temperature and strain rate influence on AA5086 Forming Limit Curves: Experimental results and discussion on the validity of the M-K model, Int. J. Mech. Sci. 78 (2014) 27-34, doi:10.1016/j.ijmecsci.2013.11.002

${ }^{21}$ H. Yao, J. Cao, Prediction of forming limit curves using an anisotropic yield function with prestrain induced backstress, Int. J. Plasticity 18 (2002) 8, 1013-1038, doi:10.1016/s07496419(01)00022-5

${ }^{22}$ J. He, D. Zeng, X. Zhu, Z. Cedric Xia, S. Li, Effect of nonlinear strain paths on forming limits under isotropic and anisotropic hardening, Int. J. Solids Struct. 51 (2014) 2,402-415, doi:10.1016/ j.ijsolstr.2013.10.013

${ }^{23}$ N. E. Prasad, A. Gokhale, R. J. H. Wanhill, Aluminum-Lithium Alloys: Processing, Properties, and Applications, 2014, 240.

${ }^{24}$ X. G. Jiang, J. C. Earthman, F. A. J. J.O. M. . Mohamed, Cavitation and cavity-induced fracture during superplastic deformation, J. Mater. Sci. 29 (1994) 21, 5499-5514, doi:10.1007/BF00349941
${ }^{25}$ E. M. Taleff, D. R. Lesuer, J. J. M. Wadsworth, M. T. A, Enhanced ductility in coarse-grained Al-Mg alloys, Metall. Mater. Trans. A Phys. Metall. Mater. Sci. 27 (1996) 2, 343-352, doi:10.1007/ bf02648411

${ }^{26}$ K. C. Chan, G. Q. J. M. L. Tong, The Cavitation Behavior of a High-Strain-Rate Superplastic A16061/20SiC w Composite under Uniaxial and Equibiaxial Tension, Mater. Lett. 51 (2001) 5, 389-395, doi:10.1016/S0167-577X(01)00326-3

${ }^{27}$ C. C. Bampton, J. W. Edington, The Effect of Superplastic Deformation on Subsequent Service Properties of Fine Grained 7475 Al, J. Eng. Mater. Technol. 105 (1983) 1, 55, doi:10.1115/1.3225619

${ }^{28} \mathrm{Z}$. Gronostajski, The constitutive equations for FEM analysis, J. Mater. Process. Technol. 106 (2000) 1, 40-44, doi:10.1016/s09240136(00)00635-x

${ }^{29}$ Z. Marciniak, A. Konieczny, Modelling the variation of the yield stress within the temperature range typical for cold and warm metal forming, J. Mater. Process. Technol. 15 (1987) 1, 15-37, doi:10.1016/0378-3804(87)90004-0

${ }^{30}$ L. Jia, X. Ren, H. Hou, Y. Zhang, Microstructural evolution and superplastic deformation mechanisms of as-rolled 2A97 alloy at low-temperature, Mater. Sci. Eng. A 759 (2019) 19-29, doi:10.1016/j.msea.2019.04.102

${ }^{31}$ P. A. Friedman, W. B. Copple, Superplastic response in Al-Mg sheet alloys, J. Mater. Eng. Perform. 13 (2004) 3, 335-347, doi:10.1361/ 10599490419162

${ }^{32}$ Y. Xun, M. J. Tan, K. M. Liew, EBSD characterization of cavitation during superplastic deformation of Al-Li alloy, J. Mater. Process. Technol., 162-163 (2005), 429-434, doi:10.1016/j.jmatprotec. 2005.02.033

${ }^{33}$ H. Y. Wu, Cavitation characteristics of a superplastic 8090 al alloy during equi-biaxial tensile deformation, Mater. Sci. Eng. A 291 (2000) 1-2, 1-8, doi:10.1016/s0921-5093(00)00986-2

${ }^{34}$ Z. Y. Ma, R. S. Mishra, Cavitation in superplastic 7075Al alloys prepared via friction stir processing, Acta Mater. 51 (2003) 12, 3551-3569, doi:10.1016/s1359-6454(03)00173-3 